\title{
PENGARUH LUAS LAHAN PERTANIAN TERHADAP TINGKAT PENDAPATAN PETANI PADA DESA KEBONAGUNG KECAMATAN BALEREJO KABUPATEN MADIUN
}

\author{
Dianita Maria Roos Pandanwangi \\ Mahasiswa Prodi Pendidikan Ekonomi IKIP PGRI Madiun
}

\begin{abstract}
Abstrak.
The study entitled The Influence Of The Width Of The Agricultural Land To The Farmers Income Level In Kebonagung Village, Balerejo, Madiun has purposes : first, to determine wether the area of the agricultural land has real influence to the farmers income in Kebonagung Village, Balerejo, Madiun. Second, to determine wether the agricultural land partially gives influence to the farmers income in Kebonagung Village Balerejo Madiun.

Based on the result of data processing and simultaneously testing on a real level (a) $=5 \%$ indicates that the width of agricultural land stimultaneously has influence to the farmers income. It can be seen from the $F_{\text {count }} 523,132$, while $F_{t}$ 3,97. In the other hand the $\operatorname{Sig}_{\text {hit }} 0,000$ and $\operatorname{Sig}_{\text {prob }}$ 0,05. The big influence of the land to the farmers income is shown by $\mathrm{R}_{\text {square }} 0,876$. It means that $87 \%$ of the farmers income is influenced by the size of the land. While the rest $13 \%$ is influenced by another factor which are not included in this study.

The result of $t$ test on agricultural land partially give influence it positively gives influence to the farmers income in Kebonagung Village, Balerejo, Madiun. It is proven by the analysis resulth that shows the $\mathrm{t}_{\text {count }} 232,8727, \mathrm{t}_{\text {tabel }} 1,665$ or $\mathrm{Sig}_{\text {hit }}$ $0,000 \leq \operatorname{Sig}_{\text {prob }} 0,05$

However, when it's seen from the regretion equation the size of the land has negative influence. It's shows by the regretion equation $\mathrm{Y}=-145966,589+$ $1,0105 \mathrm{X}$. It can be condtuded from the regretion equation, that it the size of the land is increased by $1 \%$. The income of the farmers will be decreased $1,0105 \mathrm{X}$, while another factor a held constant.
\end{abstract}

Keywords: Agricultural Land, Income

\section{Pendahuluan}

Mayoritas penduduk Indonesia yang sebagian besar tinggal di daerah perdesaan hingga saat ini masih menyandarkan mata pencahariannya pada sektor pertanian (Dumairy,1999: 204). Begitu pula dengan masyarakat yang ada di Desa Kebonagung. Menurut H.W. Widjaja (2003: 26) Desa adalah kesatuan masyarakat hukum yang memiliki kewenangan untuk mengatur dan mengurus kepentingan masyarakat berdasarkan asal-usul dan adat istiadat setempat yang diakui dalam sistem pemerintahan nasional dan dibawah kabupaten.

Sedangkan Desa menurut UU Nomor 32 Tahun 2004 Pasal 1 Ayat 12 Tentang Pemerintahan Daerah mendefinisikan pengertian desa sebagai berikut 
desa adalah kesatuan masyarakat hukum yang memiliki batas-batas wilayah yang berwenang untuk mengatur dan mengurus kepentingan masyarakat setempat, berdasarkan asal-usul dan adat istiadat setempat yang diakui dan dihormati dalam sistem pemerintah negara kesatuan republik indonesia.

Dumairy (1999: 204-205) berpendapat bahwa pertanian merupakan basis perekonomian Indonesia. Walaupun sumbangsihnya disektor pertanian dalam perekonomian diukur berdasarkan proporsi nilai tambahnya dalam membentuk produk domestik bruto atau pendapatan nasional tahun demi tahun kian mengecil, hal itu bukanlah berarti nilai dan peranannya semakin tidak bermakna. Nilai tambah sektor petanian dari waktu ke waktu kian meningkat.

Sektor pertanian yang dimaksud dalam konsep pendapatan nasional menurut lapangan usaha atau sektor produksi ialah pertanian dalam arti luas. Di Indonesia, sektor pertanian dalam arti luas ini dipilih-pilih menjadi lima subsektor yaitu: (1) Subsektor Tanaman Pangan; (2) Subsektor Perkebunan; (3) Subsektor Kehutanan; (4) Subsektor Peternakan; (5) Subsektor Perikanan.

Desa Kebonagung adalah desa yang terletak di pinggiran kota Madiun dimana masyarakat Desa Kebonagung ini sebagian besar mempunyai mata pencaharian sebagai petani. Tenaga kerja yang bekerja di bidang pertanian ini memperoleh penghasilan yang digunakan untuk memenuhi kebutuhan hidup dan meningkatkan kesejahteraan rumah tangga. Sebagian besar petani di Desa Kebonagung ini bercocok tanam pada lahan milik mereka sendiri yang mereka tanami dengan tanaman padi dan kadang kalanya lahan mereka ini disewa oleh pabrik-pabrik gula yang ada di sekitar desa ini untuk ditanami tanaman tebu. Di Desa Kebonagung selain sebagai petani mereka memiliki pekerjaan sampingan seperti peternak, pedagang, pegawai negeri, dll.

Pertanian di Desa Kebonagung sudah tergolong pertanian maju karena pertanian di Desa Kebonagung sudah menggunakan peralatan yang terbuat dari besi seperti : cangkul, traktor, bajak, dll.Sektor pertanian sangatlah penting bagi pertumbuhan ekonomi di Indonesia, ini dapat dilihat dari tingginya pendapatan nasional dalam sektor pertanian. Sadono Sukirno ( 2012: 36 ) mengemukakan bahwa Pendapatan Nasional (national income) dimaksudkan untuk menyatakan nilai barang dan jasa yang dihasilkan dalam suatu tahun tertentu. Maka dapat disimpulkan semakin banyak barang yang dihasilkan suatu negara maka semakin banyak Pendapatan Nasional yang diperoeh negara. Asfia Murni, ( 2009: 30 ) berpendapat bahwa Pendapatan Nasional yaitu nilai seluruh produk yang dihasilkan suatu negara dalam satu tahun tertentu. Disebut Pendapatan Nasional karena merupakan flow of income yang diterima masyarakat dalam bentuk balas jasa atau faktor produksi yang dimiliki. Perhitungannya didasarkan atas balas jasa yang diterima masyarakat pemilik faktor produksi atau bisa juga disebut pendekatan biaya produksi. Melalui pendekatan ini akan terlihat adanya arus biaya dalam menghasilkan produk, yakni sebagai berikut :(1) Biaya/upah yang dibayarkan kepada tenaga kerja; (2) Uang sewa yang dibayarkan kepada pemilik tanah; (3) Bunga yang dibayarkan pada pemilik modal. Semua biaya tersebut sekaligus merupakan pendapatan masyarakat. Jadi pendapatan nasional (national income) dimaksudkan untuk menyatakan nilai barang dan jasa yang dihasilkan dalam suatu negara. Dalam konsep tersebut mewakili arti Produk Domestik Bruto 
atau Produk Nasional Bruto. Sedangkan "Pendapatan atau income dari seorang warga masyarakat adalah hasil 'penjualan'nya dari faktor-faktor produksi yang dimilikinya kepada sektor produksi” (Boediono , 2002: 170 ).

Dan pendapatan pribadi dapat diartikan sebagai semua jenis pendapatan, termasuk pendapatan yang diperoleh tanpa memberikan sesuatu kegiatan apapun yang diterima oleh penduduk sesuatu negara

Boediono (2002: 170) menjelaskan bahwa income seorang warga masyarakat ditentukan oleh : (1) Jumlah faktor-faktor produksi yang mereka miliki yang bersumber pada : hasil tabungannya di tahun-tahun yang lalu, atau warisan; (2) Harga per unit dari masing-masing faktor produksi. Harga-harga ini ditentukan oleh kekuatan penawaran dan permintaan di pasar faktor produksi.

Jelas di sini bahwa harga (dari faktor produksi) hanya merupakan satu dari dua faktor yang menentukan distribusi pendapatan antar warga masyarakat. Faktor yang lain, yaitu pola pemilikan faktor-faktor produksi yang ada, merupakan faktor penentu distribusi pendapatan yang sangat penting. Harga faktor-faktor produksi (tanah, barang modal, tenaga kerja, dan kepengusahaan) ditentukan oleh kekuatan penawaran dan permintaan untuk masing-masing faktor produksi. Pendapatan yang dapat diperoleh oleh petani di Desa Kebonagung untuk setiap 1Ha sebesar 7 ton padi dimana harga jual padi basah per kwintal mencapai Rp 330.000 dan harga jual untuk padi kering per kwintal mencapai Rp 400.000.

Disini dapat kita lihat besar kecilnya dari pendapatan yang diperoleh petani di Desa Kebonagung ini dipengaruhi oleh seberapa luas lahan yang mereka miliki jadi semakin luas lahan yang mereka miliki semakin tinggi tingkat pendapatan yang mereka peroleh.

Sukanto (1998: 64) berpendapat bahwa masalah pembanguna ekonomi khusunya di dunia ketiga orang tidak akan lepas dari masalah pertanian. Sedangkan berbicara masalah pertanian kita tidak bisa terlepas dari lahan sebab pertanian ada dan tumbuh karena tersedianya lahan. Meskipun saat ini mulai dirintis pertanian tanpa lahan dengan teknologi dan sejenisnya namun paling tidak sampai beberapa dekade. Lahan untuk pertanian masih sangat dibutuhkan mengingat sangat mahalnya terknologi tersebut.

Semua masyarakat memiliki aturan-aturan menentukan pembagian sumberdaya tanah misalkan para pemburu dan peramu harus menentukan siapa yang boleh berburu binatang dan meramu tumbuh-tumbuhan dan dimana kegiatan itu boleh dilakukan (Soekadijo,2001: 46).

Soekartawi (2002: 15) berpendapat bahwa luas lahan pertanian akan mempengaruhi skala usaha, dan skala usaha ini pada akhirnya akan mempengaruhi efisiensi atau tidaknya suatu usaha pertanian. Seringkali dijumpai, makin luas lahan yang dipakai sebagai usaha pertanian akan semakin tidak efisienlah lahan tersebut. Hal ini didasarkan pada pemikiran bahwa luasnya lahan mengakibatkan upaya melakukan tindakan yang mengarah pada segi efisiensi akan berkurang, karena: (1) Lemahnya pengawasan terhadap penggunaan faktor produksi seperti bibit, pupuk, obat-obatan, dan tenaga kerja; (2) Terbatasnya persediaan tenaga kerja di sekitar daerah itu yang pada akhirnya akan mempengaruhi efisiensi usaha pertanian tersebut; (3) Terbatasnya persediaan modal untuk membiayai usaha pertanian dalam skala luas tersebut 
Sebaliknya pada luas lahan yang sempit, upaya pengawasan terhadap penggunaan faktor produksi semakin baik, penggunaan tenaga kerja tercukupi dan tersedianya modal juga tidak terlalu besar, sehingga usaha pertanian seperti ini sering lebih efisien. Meskipun demikian, luasan yang terlalu kecil cenderung menghasilkan usaha yang tidak efisien pula.

Dari pernyataan diatas maka dapat ditarik sebuah kesimpulan bahwa sebenarnya lahan yang sangat luas belum tentu memngasilkan keuntungan yang besar pula bahkan malah sebaliknya ini dikarenakan semakin luas lahan yang dimiliki seseorang maka semakin besar biaya yang dikeluarkan untuk kegiatan produksi.

Sebelumnya perlu dijelaskan terlebih dahulu apa pengertian tanah dan ada pengertian lahan. Hal ini perlu karena dalam kehidupan sehari-hari orang sering tidak membedakan antara lahan dan tanah. Perbedaan dan persamaan tanah dan lahan dapat diambil inti sarinya dari pengertiaan keduanya berikut ini :

Sintanala Ardsyad (Dirjen Pendidikan,2005: 7), mengatakan bahwa tanah adalah suatu benda alami heterogen yang terdiri atas komponen-komponen padat, cair dan gas dan mempunyai sifat dan perilaku yang dinamik.

Tanah adalah tubuh alam yang tersusun dalam bentuk profil. Tanah terdiri dari berbagai campuran mineral pecah lapuk dan organik pengurai, sebagai lapisan tipis penutup permukaan bumi, serta menjamin tumbuhnya tumbuhan, hewan, dan manusia (Rita Hanafie, 2010: 52).

Sedangkan lahan menurut Sintanala Arsyad (Dirjen Pendidikan, 2005: 9) adalah satuan wilayah dimuka bumi yang memiliki nilai-nilai atau karakteristik tertentu berkaitan dengan fungsi atau kegunaan yang melekat pada peruntukannya. Penggunaan lahan diartikan sebagai bentuk campur tangan manusia terhadap lahan dalam rangka memenuhi kebutuhan hidupnya. Kebutuhan tersebut bisa berupa kebutuhan materiil maupun kebutuhan spiritual. Penggunaan lahan untuk pertanian di Indonesia dapat dibedakan menjadi dua yaitu : (1) Pertanian Primitif; dan (2) Pertanian Maju. Rita Hanafie (2010: 54-56) berpendapat bahwa secara mikro pengaruh tanah dalam pertanian dilihat dari penguasaan lahan, luas lahan garapan dan nilai lahan. Macam-macam lahan menurut kepemilikan oleh petani dibedakan menjadi: (1) Lahan yang dibeli, baik kontan maupun angsuran; (2) Lahan warisan, yaitu lahan yang diterima oleh ahli waris berdasarkan pembagian dari harta orangtua yang telah meninggal dunia; (3) Lahan yang diperoleh secara hibah, yaitu lahan yang diterima/didapat secara cuma-cuma dari badan/harta orang yang masih hidup; (4) Lahan yang dimiliki berdasarkan land reform, permohonan biasa, pembagian lahan trasmigrasi, pembagian lahan dari pembukaan hutan, hukum adat, atau penyerahan dari program Perkebunan Inti Rakyat; (5) Lahan sewa, yaitu lahan yang didapat dengan perjanjian sewa, yang besarnya sewa sudah ditentukan terlebih dahulu tanpa melihat besar/kecilnya hasil produksi/pembayaran sewa dapat berupa uang atau barang. Dalam sewa-menyewa, pemilik lahan tidak ikut menanggung ongkos-ongkos produksi dan resiko dari penggarapan lahannya; (6) Lahan bagi hasil (sakap), yaitu lahan sewa tetapi dengan perjanjian besar sewa berdasarkan hasil panen/produksi dan dibayarkan setelah panen. Besarnya bagian yang akan diserahkan pada pemilik lahan sudah ditentukan terlebih dahulu, seperti setengah 
atau sepertiga hasil produksi; (7) Lahan gadai, yaitu lahan yang berasal dari pihak lain sebagai jaminan pinjaman uang pihak yang menggadaikan lahan. Lahan tersebut dikuasai oleh orang yang memberi pinjaman uang sampai pemilik lahan membayar kembali hutangnya; (8) Lahan bengkok/pelungguh, yaitu lahan milik desa/kelurahan yang dikuasai kepada pamong desa atau bekas pamong desa sebagai gaji atau pension; (9) Lahan bebas sewa, serobotan, dan lahan garapan. Lahan bebas sewa adalah lahan yang didapat dengan tanpa membeli atau membayar sewa dan bukan merupakan lahan milik tetapi hanya diizinkan memakai dengan bebas sewa; (10) Lahan yang dikuasai adalah lahan milik sendiri ditambah lahan yang berasal dari pihak lain dan dikurangi lahan yang berada di pihak lain. Lahan tersebut lahan sawah dan atau lahan bukan sawah; (11) Lahan pertanian adalah lahan yang dikuasai dan pernah diusahakan untuk pertanian selama setahun yang lalu. Lahan tersebut mencakup lahan sawah, huma, ladang, tegal/kebun, kolam/tebat/empang, lahan perkebunan, hutan, dan lahan untuk penggembalaan/padang rumput; (12) Lahan sawah adalah lahan pertanian yang berpetak-petak dan dibatasi oleh pematang, saluran untuk menahan/menyalurkan air yang biasanya ditanami padi sawah tanpa mengandung dari mana diperolehnya atau status lahan tersebut. Lahan sawah dibedakan menjadi: (a) Lahan sawah irigasi, yaitu lahan sawah yang mendapatkan air dari sistem irigasi, baik bangunan penyadap dan jaringannya yang dikelola oleh instansi pemerintah seperti Dinas Perairan maupun oleh masyarakat; (b) Lahan sawah tanpa irigasi yang meliputi sawah tadah hujan dan sawah pasang surut; (13) Lahan bukan sawah adalah semua lahan sawah yang biasanya ditanami dengan tanaman musiman atau tanaman tahunan; (14) Huma adalah lahan kering yang biasanya ditanami tanaman musiman atau tanaman hanya dua musim, kemudian ditinggalkan bila sudah tidak subur lagi dan akan digarap kembali bila kesuburannya sudah kembali; (15) Ladang/tegal/kebun adalah lahan kering yang ditanami tanaman musiman atau tanaman tahunan serta terpisah dengan halaman sekitar rumah dan penggunaanya tidak berpindah-pindah; (16) Lahan tidur adalah lahan yang biasanya digunakan untuk usaha pertanian, tetapi tidak dimanfaatkan lebih dari 2 tahun.

\section{Pertanian di Indonesia}

Negara Indonesia adalah Negara agraris, karena sebagian besar dari penduduknya bermata pencaharian sebagai petani. Sebagai lahan pertanian, tanah di Indonesia terkenal sangat subur karena bahan induk pembentuk tanah berasal dari gunung berapi. Besarnya jumlah penduduk Indonesia merupakan salah satu modal yang cukup besar untuk meningkatkan pembangunan nasional, terutaman di sektor pertanian. Namun demikian penduduk yang besar sekalian juga menjadi kendala pembangunan sektor pertanian, karena rata-rata kepemilikan lahan juga akan semakin sempit. Pembangunan sektor pertanian diarahkan untuk meningkatkan pendapatan dan tingkat kesejahteraan bangsa Indonesia.

Untuk mencapai tujuan tersebut perlu adanya peningkatan kualitas hidup bangsa terutama pada sektor ketenagakerjaan. Dengan adanya tenaga kerja yang berkualitas maka diharapkan dapat meningkatkan produksi pertanian terutama pangan, sehingga bangsa Indonesia bisa berswasembada pangan, meningkatkan 
usaha pertanian dengan panca usaha pertanian, pemanfaatan lahan secara optimal dengan memperhitungkan kebutuhan dimasa sekarang dan tetap menjaga kelestarian untuk masa-masa yang akan datang.

Kegiatan penduduk Indonesia di sektor pertanian sekarang ini dapat dibedakan menjadi 2 kelompok yaitu : (1) Pertanian Rakyat; dan (2) Pertanian Perkebunan.

\section{METODE PENELITIAN}

Penelitian ini dilakukan di Desa Kebonagung, Kecamatan Balerejo Kabupaten Madiun dan yang digunakan sebagai objek penelitian dalam skripsi ini adalah kelompok tani yang ada di Desa Kebonagung Kecamatan Balerejo Kabupaten Madiun.

Peneliti memilih kelompok tani dengan alasan belum adanya informasi mengenai bagaimana dan seberapa besar pengaruh luas lahan terhadap pendapatan petani di Desa Kebonagung, Kecamatan Balerejo, Kabupaten Madiun dan juga karena Desa Kebonagung merupakan daerah potensial penghasil padi dibandingkan daerah lainnya di Kecamatan Balerejo karena lahan pertanian di Desa Kebonagung masih sangat luas.

Penelitian ini merupakan penelitian deskriptif yaitu penelitian yang mengarah pada pengungkapan suatu masalah atau keadaan sebagaimana adanya dan mengungkapkan fakta-fakta yang ada.

Dalam penelitian ini peneliti menentukan dua variabel yaitu variabel bebas (X) adalah Luas Lahan dan variabel terikat (Y) adalah Tingkat Pendapatan.

Dilihat dari subjek penelitian, maka penelitian ini termasuk penelitian populasi karena responden penelitian ini adalah 76 petani padi dari 326 petani dari 4 kelompok tani yang ada di Desa Kebonagung Kecamatan Balerejo Kabupaten Madiun.

Metode yang digunakan dalam penelitian ini adalah Proportionate Stratifield Random Sampling dimana setiap anggota dari kelompok tani berkesempatan menjadi responden. Cara yang digunakan untuk menentukan berapa orang yang dijadikan responden dalam setiap kelompok tani yaitu menggunakan rumus slovin. Pendapat Slovin dalam Husein Umar (2011:79) tentang pengambilan ukuran sampel digunakan rumus Slovin yaitu:

dimana:

$$
\mathrm{n}=\frac{\mathrm{N}}{1+\mathrm{N} \mathrm{e}^{2}}
$$

$$
\begin{aligned}
\mathrm{n}= & \text { ukuran sampel } \\
\mathrm{N}= & \text { ukuran populasi } \\
\mathrm{e}= & \text { persen kelonggaran ketidakketelitian karena kesalahan } \\
& \text { pengambilan sampel yang masih dapat ditolerir atau diinginkan } \\
& \text { yakni } 10 \% .
\end{aligned}
$$

Dari jumlah populasi tersebut diambil sampel menggunakan rumus Slovin sebagai berikut :

Keterangan :

$$
\mathrm{n}=\frac{N}{1+N e^{2}}
$$




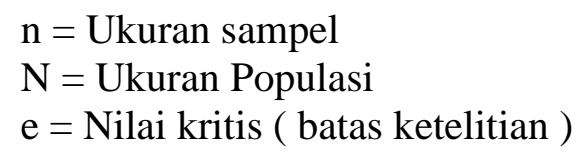

Berdasarkan rumus Slovin dengan nilai kritis (e) yang digunakan sebesar $10 \%$, dengan jumlah populasi $(\mathrm{N})$ sebesar 326. Dengan demikian jumlah sampel (n) dalam penelitian ini adalah :

$$
\begin{aligned}
& \mathrm{n}=\frac{N}{1+N e^{2}} \\
& \mathrm{n}=\frac{326}{1+(326)(10 \%)^{2}} \\
& \mathrm{n}=\frac{326}{1+(326)(0,1)^{2}} \\
& \mathrm{n}=76,52
\end{aligned}
$$

Hasil penelitian menunjukkan bahwa jumlah sampel adalah sebanyak 76,52 sampel, sehingga dibulatkan menjadi 76 sampel. Selanjutnya pengambilan jumlah sampel penelitian di masing-masing kelompok tani ditentukan dengan menggunakan metode Proportionate Stratified Random Sampling

1. Tani Maju $1=83 / 326 \times 76=19$

2. Tani Maju $2=80 / 326 \times 76=19$

3. Lembah Agung $=85 / 326 \times 76=19$

4. Sumber Agung $=78 / 326 \times 76=19$

Total Sampel $=76$

Dalam penelitian ini teknik pengumpulan data yang digunakan adalah wawancara, observasi, tabulasi dan dokumentasi.

Wawancara yang dilakukan dalam penelitian ini merupakan wawancara terstruktur dengan menggunakan kuesioner. Kuesioner yang digunakan dalam penelitian ini adalah kuesioner terbuka, dimana peneliti memberikan kebebasan pada responden untuk memberikan jawaban.

Observasi adalah cara dan teknik pengumpulan data dengan melakukan pengamatan dan pencatatan secara sistematis terhadap gejala atau fenomena yang ada pada obyek penelitian.

Tabulasi merupakan usaha penyusunan data yang diperoleh dari responden untuk bahan analisis lebih lanjut dalam bentuk tabel, penyederhanaan data agar lebih mudah dalam melakukan analisis. Tabel yang digunakan dalam penelitian ini adalah tabel frekuensi.

\section{HASIL PENELITIAN}

\section{Variabel Luas Lahan}

Dari hasil pengujian statistik deskriptif dengan jumlah responden sebanyak 76 dapat diketahui statistik deskriptifnya sebagai berikut : (1) Nilai mean sebesar 1,217; (2) Nilai median sebesar 1,000; (3) Nilai modus sebesar 1,0; (4) Nilai minimum sebesar 0,5; (5) Nilai maksimum sebesar 2,0; (6) Jumlah total sebesar 92,5 ; dan (7) Standar deviasi sebesar 0,5313 
Luas Lahan yang dimiliki oleh 76 petani yang di dapat dari penyebaran kuisioner di Desa Kebonagung Kecamatan Balerejo Kabupaten Madiun maka didapatkan data rata-rata lahan yang dimilik petani seluas $1 \mathrm{Ha}$ sedangkan luas lahan paling rendah adalah $0,5 \mathrm{Ha}$ dan yang paling luas adalah $2 \mathrm{Ha}$. Dari penelitian ini di dapat nilai modus sebesar $1 \mathrm{Ha}$ dan nilai minimum sebesar 0,5 $\mathrm{Ha}$ dan nilai maksimum sebesar $2 \mathrm{Ha}$

\section{Variabel Tingkat Pendapatan}

Dari hasil pengujian statistik deskriptif dengan jumlah responden sebanyak 76 dapat diketahui statistik deskriptifnya sebagai berikut:(1) Nilai mean sebesar 1,21533; (2) Nilai median sebesar 1,04585; (3) Nilai modus sebesar 8.975.000; (4) Nilai minimum sebesar 3.000.000; (5) Nilai maksimum sebesar 22.500.000;

(6) Jumlah total sebesar 9.23; (7) Standar deviasi sebesar 5735720.609

Pendapatan yang diperoleh oleh 76 petani berdasarkan jawaban pada kuesioner didapat data pendapatan untuk luas lahan 0,5 Ha berpenghasilan kisaran Rp 3.000.000 sampai dengan Rp 5.000.000 sedangkan untuk petani yang memiliki lahan $1 \mathrm{Ha}$ dapat memperoleh penghasilan $\mathrm{Rp} 5.000 .000$ sampai dengan $\mathrm{Rp}$ 10.000.000 dan untuk petani yang memiliki lahan $2 \mathrm{Ha}$ dapat memperoleh penghasilan $\mathrm{Rp}$ 10.000.000 sampai dengan Rp 22.000.000. Dari penelitian ini didapat nilai modus sebesar $\mathrm{Rp} 8.975 .000$, dan nilai minimum sebesar $\mathrm{Rp}$ 3.000.000 dan nilai maksimum sebesar Rp 22.500.000

\section{Uji Korelasi}

Dalam uji korelasi diperoleh nilai $r_{\text {hitung }} \geq r_{\text {tabel }}(0,936 \geq 0,220)$ atau $S i g_{\text {hit }}$ $\leq \operatorname{Sig}_{\text {prob }}(0,000 \leq 0,05)$. Selain itu diketahui pula nilai $\mathrm{R}^{2}$ sebesar $87,60 \%$, dari sini dapat dikatakan bahwa sebesar $87,60 \%$ variabel terikat (Y) dalam penelitian ini pendapatan petani dipengaruhi oleh luas lahan sebagai variabel bebas $(\mathrm{X})$ dan sedangkan sisanya $12,40 \%$ dipengaruhi oleh faktor lain.

Dalam hal ini $\mathrm{H}_{0}$ ditolak dan $\mathrm{H}_{1}$ diterima, artinya ada hubungan antara luas lahan terhadap pendapatan petani di Desa Kebonagung Kecamatan Balerejo Kabupaten Madiun.

\section{Uji Fisher}

Untuk uji Fisher diperoleh hasil nilai $F_{\text {hitung }} \geq F_{\text {tabel }}(523,132 \geq 3,97)$ dan Sig $_{\text {hit }} \leq \operatorname{Sig}_{\text {prob }}(0,000 \leq 0,05)$. Dengan demikian dapat disimpulkan bahwa $\mathrm{H}_{0}$ ditolak dan $\mathrm{H}_{1}$ diterima, artinya luas lahan memiliki pengaruh terhadap pendapatan petani di Desa Kebonagung Kecamatan Balerejo Kabupaten Madiun.

\section{Uji t}

Dari hasil analisis koefisien regresi atau uji t diperoleh nilai $t_{\text {hitung }}$ sebesar $232,872 \geq t_{\text {tabel }}$ sebesar 1,665 atau nilai $\operatorname{Sig}_{\text {hit }}$ sebesar $0,000 \leq \operatorname{Sig}_{\text {prob }}$ 0,05. Maka dapat disimpulkan bahwa $\mathrm{H}_{0}$ ditolak dan $\mathrm{H}_{1}$ diterima yang berarti ada beda pengaruh luas lahan dengan pendapatan petani di Desa Kebonagung Kecamatan Balerejo Kabupaten Madiun.

Lebih lanjut apabila dilihat dalam persamaan regresi diperoleh persamaan nilai $\mathrm{Y}=-145966.589+1.0105 \mathrm{X}$. Dengan demikian dapat disimpulkan dari persamaan garis regresi tersebut dapat dilihat jika luas lahan meningkat sebanyak $1 \%$ maka pendapatan petani akan menurun sebesar $1.0105 \mathrm{X}$, sedangkan faktor lainnya dianggap tetap. 


\section{PENUTUP \\ Simpulan}

Berdasarkan pembahasan hasil penelitian yang telah dikemukakan di bab sebelumnya, maka dapat disimpulkan sebagai berikut :

Luas Lahan yang dimiliki oleh 76 petani yang di dapat dari penyebaran kuisioner di Desa Kebonagung Kecamatan Balerejo Kabupaten Madiun maka didapatkan data rata-rata lahan yang dimilik petani seluas $1 \mathrm{Ha}$ sedangkan luas lahan paling rendah adalah $0,5 \mathrm{Ha}$ dan yang paling luas adalah $2 \mathrm{Ha}$. Dari penelitian ini di dapat nilai modus sebesar $1 \mathrm{Ha}$ dan nilai minimum sebesar $0,5 \mathrm{Ha}$ dan nilai maksimum sebesar $2 \mathrm{Ha}$

Pendapatan yang diperoleh oleh 76 petani berdasarkan jawaban pada kuesioner didapat data pendapatan untuk luas lahan 0,5 Ha berpenghasilan kisaran Rp 3.000.000 sampai dengan Rp 5.000.000 sedangkan untuk petani yang memiliki lahan $1 \mathrm{Ha}$ dapat memperoleh penghasilan Rp 5.000.000 sampai dengan Rp 10.000.000 dan untuk petani yang memiliki lahan 2 Ha dapat memperoleh penghasilan $\mathrm{Rp}$ 10.000.000 sampai dengan Rp 22.000.000. Dari penelitian ini didapat nilai modus sebesar $\mathrm{Rp}$ 8.975.000, dan nilai minimum sebesar $\mathrm{Rp}$ 3.000.000 dan nilai maksimum sebesar Rp 22.500.000

Hasil yang diperoleh dari penelitian yang berjudul Pengaruh Luas Lahan Pertanian Terhadap Tingkat Pendapatan Petani Pada Desa Kebonagung Kecamatan Balerejo Kabupaten Madiun dapat disimpulkan secara parsial Faktor luas lahan berpengaruh secara positif terhadap pendapatan petani di Desa Kebonagung Kecamatan Balerejo Kabupaten Madiun ini dibuktikan dari hasil analisis yang menunjukkan nilai $t_{\text {hitung }}$ sebesar 232,872 $\geq t_{\text {tabel }}$ sebesar 1,665 atau nilai $S_{i g} g_{\text {hit }}$ sebesar $0,000 \leq$ Sig $_{\text {prob }} 0,05$. Akan tetapi apabila dilihat dari persamaan regresi faktor luas lahan berpengaruh negatif yang ditunjukkan dalam persamaan regresi diperoleh persamaan nilai $\mathrm{Y}=-145966.589+1.0105 \mathrm{X}$. Dengan demikian dapat disimpulkan dari persamaan garis regresi tersebut dapat dilihat jika luas lahan meningkat sebanyak $1 \%$ maka pendapatan petani akan menurun sebesar $1.0105 \mathrm{X}$, sedangkan faktor lainnya dianggap tetap. Dari persamaan regresi ini maka berlakulah hukum The Law Of Diminishing Returns sebuah hukum ekonomi yang menjelaskan tentang proporsi input yang tepat untuk mendapatkan output maksimal dimana apabila input yang kita miliki melebihi kapasitas produksi dari input maka return (pendapatan) kita akan semakin menurun.

\section{Saran}

Berdasarkan simpulan yang telah diuraikan, maka dapat diajukan saran sebagai berikut :

\section{Bagi Petani}

Petani Padi di Desa Kebonagung Kecamatan Balerejo Kabupaten Madiun disarankan agar dapat terus meningkatkan produktivitas dengan memanfaatkan segala faktor-faktor produksi yang dimilikinya secara maksimal dan efisien.

\section{Bagi Pemerintah}

Pemerintah melalui Dinas Pertanian hendaknya lebih meningkatkan kinerja sebagai sumber informasi bagi petani dalam penanganan dan pengelolaan tanaman padi melalui penyuluhan-penyuluhan yang berkala sehingga diharapkan produksi 
padi yang dihasilkan menjadi lebih berkualitas dan dapat meningkatkan pendapatan petani serta dapat meningkatkan pasokan pangan bagi Negara.

\section{Bagi Kelompok Tani}

Kelompok Tani yang ada di Desa Kebonagung Kecamatan Balerejo Kabupaten Madiun disarankan agar mendirikan Gubuk Pertanian yang bertujuan sebagai sarana prasarana petani untuk melakukan penyuluhan dan sebagai tempat pertemuan yang bertujuan untuk meningkatkan produktivitas dari hasil pertanian .

\section{DAFTAR PUSTAKA}

Asfia Murni. 2009. Ekonomika Makro. Bandung: PT Refika Aditama

A.W. Widjaja. 2003. Pemerintah Desa dan Administrasi Desa. Jakarta: PT. RAJA GRAFINDO PERSADA

Boediono. 2002. Pengantar Imu Ekonomi No. 1 Ekonomi Makro. Yogyakarta: BPFE-Yogyakarta.

Cholid Narbuko, H.Abu Achmadi, 1999, Metodologi Penelitian, Jakarta: PT. BUMI AKSARA.

Direktorat Jenderal Pendidikan Dasar dan Menengah, 2005, Ilmu Pengantar Sosial-Geografi.

Dumairy, 1999, Perekonomian Indonesia, Jakarta: Erlangga.

Imam Ghozali, 2005, Aplikasi Analisis Multivariate dengan Program SPSS, Semarang: BP. UNDIP.

Husein Umar, 2011, Metode Penelitian Untuk Skripsi Dan Tesis Bisnis, Jakarta: PT. RAJA GRAFINDO PERSADA.

Mubyarto, 1985, Peluang Kerja Dan Berusaha Di Pedesaan, Yogyakarta: BPFEYogyakarta.

Rita Hanafie, 2010, Pengantar Ekonomi Pertanian, Yogyakarta: CV ANDI OFFSET.

Sadono Sukirno, 2012, Makro Ekonomi Teori Pengantar, Jakarta: PT Raja Grafindo.

Soekadijo, 2001, Antropologi, Jakarta: Erlangga.

Soekartawi, 2002, Prinsip Dasar Ekonomi Pertanian, Jakarta: PT Raja Grafindo.

Suhardjono, 2008, Manajemen Perkreditan Usaha Kecil dan Menengah,Yogyakarta: AMP YKPN. 
Suharsimi Arikunto, 2010, Prosedur Penelitian, Jakarta: Rineka Cipta.

Sukanto Reksohadiprojo, 1998, Ekonomi Sumber Daya Alam dan Energi, Yogyakarta: BPFE-Yogyakarta.

Mul irawan, 2010 http://mullrawan.wordpress.com/category/the-law-ofdiminishing-return-hukum-hasil-yang-menurun/, Posted by mul_irawan pada 24/08/2010 diunduh 19 maret 2013 pukul 20.00 wib. 